\title{
Carcass characteristics and meat quality of Aberdeen Angus steers finished on different pastures
}

\author{
Thais Devincenzi ${ }^{1}$, Carlos Nabinger ${ }^{1}$, Fernando Flores Cardoso ${ }^{2}$, Élen Silveira Nalério ${ }^{2}$, Igor \\ Justin Carassai ${ }^{1}$, Jean Kássio Fedrigo ${ }^{1}$, Jaime Urdapilleta Tarouco ${ }^{1}$, Leandro Lunardini Cardoso ${ }^{1}$ \\ ${ }^{1}$ Programa de Pós-Graduação em Zootecnia - Universidade Federal do Rio Grande do Sul (UFRGS) - Av. Bento Gonçalves, 7712, \\ 91501-970 - Porto Alegre, RS. \\ 2 Embrapa Pecuária Sul - Bagé, RS.
}

\begin{abstract}
The present study was conducted to assess carcass features, physicochemical and sensory parameters of meat from steers finished on three types of pastures: natural pasture; natural pasture improved, fertilized and oversown with winter species; and annual summer grassland. The experiment was conducted from December 14, 2009 to November 30, 2010, with treatments distributed in a completely randomized design with a different number of replicates. Animals were used as experimental units. Experimental animals were Aberdeen Angus steers with twenty months of initial age and $354 \pm 27.4 \mathrm{~kg}$ of live weight, on average. The highest average daily gains were obtained for the annual summer grassland. There was no effect of treatments on carcass conformation. The highest carcass yield was obtained on the improved natural pasture. Forequarter yield, side cut yield and longissimus muscle area were similar between the pastures. Moisture and total lipids were not affected by the pasture. Thawing and cooking losses were higher in improved natural pasture and lower in sorghum pasture. Regardless of the treatment, the meat had luminosity ranging from intermediate to dark, high in red, high in yellow, and considered within the normal range for beef. Meat of higher shear force was found in natural pasture, and lower shear force was observed in meat from annual summer grassland. Average live weight daily gain explained 18\% of the shear force. Sensory evaluation by duo-trio test showed differences between samples from distinct pastures in flavor. All the studied systems allow for desirable characteristics in carcass and meat.
\end{abstract}

Key Words: average daily gain, fertilized natural pasture, sensory panel, sorghum pasture, tenderness

\section{Introduction}

In Southern Brazil, the main nutritional base of the livestock production is still the rangelands of Bioma Pampa. (Sebrae/Senar/Farsul, 2005). The herbage vegetation with a huge floristic biodiversity (Boldrini, 2002) provides conditions to sustainable production of meat products, which can be one of the ways to supply the current demand of the market and provide financial advantages to farmers (Nabinger \& Sant'Anna, 2007). Besides that, rangelands play an important ecological role, which makes their conservation indispensable (Bencke, 2009). Nowadays, consumers have been demanding information about the method of production, food insurance warranties and also, the appeal for products engaged in environmental conservancy has been observed the (Prache \& Thériez, 1999). Producing beef on natural grasslands concomitantly with nature conservation may present a method to provide with a huge part of these demands. However, beef produced in this environment should not only show ecological value, but also have the basic quality attributes desired by consumers: shiny red color, little fat covering, tenderness, juiciness and an pleasant taste (Felício, 1998).

The correct managing of the rangeland allows slaughtering steers with up to four definitive teeth exclusively based on this resource (Castilhos et al., 2007; Ferreira, 2009). Besides that, this production system offers lots of advantages, increasing the outcome rate, farm productivity, a higher rate of return and better business economic efficiency (Gottschall, 2005).

On the other hand, annual pasturelands such as Sorghum sp. are an alternative which would allow minimizing the steers finishing period due to high individual weight gains (Restle et al., 1996; Muehlmann et al., 1997), even thought that would represent higher costs than the natural grasslands.

In light of this, it is necessary to develop studies about meat quality produced on the different alternatives of grasslands in Southern Brazil. Therefore, the objective of this study was to evaluate the carcass characteristics and physicochemical and sensorial aspects of Aberdeen Angus beef cattle finished on natural grassland, improved natural 
grassland oversown with winter species and fertilization and annual summer-grassland.

\section{Material and Methods}

The experiment was carried out on a private farm located in Dom Pedrito rural area (31⒉21'39.26"S 54³4'56.20" W) between $12 / 14 / 2009$, and 11/29/2010. The climate, according to the Köppen classification system, was a Cfa 2 (subtropical climate) and the soil was a Mollisol with vertisol properties (Chernossolo Háplico Órtico Vértico) (Streck et al., 2002). The experimental area was composed of five paddocks with approximately 15 ha each. The treatments were three systems of cattle finishing based on pastures: natural grassland; semi-natural grassland; natural grassland oversown with cultivated winter species + fertilization; and annual summer-grassland (Sorghum). Mechanical-mowing in the natural grassland system was done in May and September, 2010, aiming at the weed control and the sward maintenance.

On the semi-natural grassland, the soil acidity was corrected with three tons of lime per hectare in November 2009. In March 2010, fertilization using $200 \mathrm{~kg} / \mathrm{ha}$ of diammonium phosphate (DAP: 18-45-00) was done. In May 2010, mechanical mowing and urea application (100 kg/ha) were conducted. At that time, $36 \mathrm{~kg}$ of Lolium multiflorum Lam. pure live seed/ha, $5.4 \mathrm{~kg}$ of Lotus corniculatus cv. São Gabriel pure live seed/ha), both spread, were oversown.

At the end of the fattening cycle, which is the period of highest body fat deposition on the animals, the floristic evaluation in the natural grasslands-based finishing systems was proceeded using Botanal method (Tothill, 1978). In natural grassland system, the species which had most contribution in the forage mass (FM) were Coelorachis selloana (20.2\%), Paspalum notatum (14.1\%), Paspalum dilatatum (9.05\%), Piptochaetium stipoides (8.6\%), Botriochloa laguroides (7.1\%) and Saccharum angustifolium (6.4\%). In semi-natural grassland system the species which had most contribution in FM were Lolium multiflorum (25.6\%), Paspalum notatum (22.4\%), Piptochaetium stipoides (13.9\%), Axonopus affinis (5.2\%) and Paspalum ditatatum (4.2\%).

A hybrid forage sorghum (Sorghum bicolor $\times$ Sorghum sudanense) cv AGR 2501 was sown in 01/01/2010 in the annual-summer grassland system. The sowing density was 22 seeds/ $\mathrm{m}$ with $0.45 \mathrm{~m}$ distance between rows in a no-tillage system. Soil acidity correction and fertilization were performed according to a prescription based on soil analysis. Animals started grazing on 02/03/2010, when the sward height was about $90 \mathrm{~cm}$. Before getting in to the sorghum pasture, the animals were in a natural grassland area which was similar to the Natural grassland system.

Experimental animals (test animals) were 43 Aberdeen Angus steers with about 20 months of age, distributed as follows: natural grasslands $(\mathrm{n}=16)$, semi-natural grasslands ( $n=18)$ and annual summer grassland $(n=9)$. The treatments natural grassland and semi-natural grassland were composed of two paddocks each, in which the animals from those treatments were distributed equally and kept until the end of the experimental period. An explanation for keeping two paddocks in natural grasslands and improved-natural grasslands is because of the higher heterogeneity of those treatments when they are compared with mono-specific pastures (e.g. sorghum pasture), therefore, monitoring their productive conditions (herbage mass, sward height, floristic composition) would be important for their characterization.

The animal average live weight in the beginning of grazing on natural grassland and improved-natural grassland (December, 2010) was $353 \pm 20.8 \mathrm{~kg}$. Animal live weight was $354 \pm 27.4 \mathrm{~kg}$ in annual-summer grassland at the beginning of grazing. Their weight was not different from the other treatments at the same period $(\mathrm{P}>0.05)$.

Natural grassland and improved-natural grasslands animals were kept in continuous grazing with variable stocking rate aiming at a forage allowance of $13 \mathrm{~kg}$ of dry matter for $100 \mathrm{~kg}$ of live weight. Besides the test animals, a variable number of regulators (Mott \& Lucas, 1952) were used. Stocking adjustment was done monthly, except for July and October, concomitantly with evaluation of forage mass and accumulation. In natural grassland and improvednatural systems, the average forage mass and height were respectively $1802 \mathrm{~kg} \mathrm{DM} / \mathrm{ha}$ and $8.9 \mathrm{~cm}$ (Table 1).

Values of forage mass and sward height were close to the range of 1,476 - 1,765 $\mathrm{kg} \mathrm{DM} / \mathrm{ha}$ recommended by Moojen \& Maraschin (2002) and between 10-12 cm of height indicated by Gonçalves et al. (2009). For these last authors, managing natural grasslands at this height corresponded to the best estimation of animal production potential. In the annual summer-grassland treatment, animals were kept in a strip stocking. The animals started grazing when the sward reached $90 \mathrm{~cm}$ height on average and the stocking rate was adjusted to demote the height until $30 \mathrm{~cm}$ in a one-week period.

Animals were monthly weighed with a 12-hour period of solid and liquid fasting. At weighing procedures, to accompany the growth and fat deposition, ultrasonic measurements of the rib eye area and fat thickness were taken between the $12^{\text {th }}$ and $13^{\text {th }}$ ribs and fat thickness on Biceps femoris on the P8 site. Production and acquisition of ultrasonic images were obtained by a main unit - eco 
Table 1 - Height, forage mass and stocking rate in different periods in natural grassland (NG) and improved grasslands (ING) (2009/2010)

\begin{tabular}{|c|c|c|c|c|c|c|c|c|c|c|}
\hline & Dec & Jan & Feb & Mar & Apr & May & Jun & Aug & Sep & Nov \\
\hline & & \multicolumn{9}{|c|}{ Sward height $(\mathrm{cm})$} \\
\hline NG & 12.7 & 7.9 & 10.4 & 11.2 & 9.8 & 6.7 & 8.3 & 7.3 & 7.2 & 12.2 \\
\hline ING & & \multicolumn{9}{|c|}{ Forage mass (kg DM/ha) } \\
\hline NG & 1,755 & 1,441 & 2,186 & 2,464 & 2,514 & 1,801 & 1,513 & 1,397 & 1,280 & 1,966 \\
\hline NG & 650 & 417 & 507 & 578 & 488 & 222 & 212 & 215 & 242 & 278 \\
\hline ING & 749 & 822 & 736 & 740 & 505 & 267 & 236 & 449 & 332 & \\
\hline
\end{tabular}

DM - dry matter; LW - live weight.

camera Aloka SSD 500 V (Eletro Medicina Berger, Ltda) equipped with a linear transducer UST 5049 with $3.5 \mathrm{MHz}$ frequency and $17.2 \mathrm{~cm}$ length.

Average daily gain (ADG, kg/day of LW) was obtained by the difference between initial and final average live weight of test animals. To allow comparisons between treatments, animals were slaughtered in the same degree of physiological maturity. Three millimeters of fat thickness was adopted as slaughter criterion.

Slaughtering procedures were carried out at Marfrig slaughterhouse, in the city of Bagé, Rio Grande do Sul state (SIF 232) on the days 06/10/2010 for animals from Annualsummer grassland treatment, 10/22/2010 for animals from the improved grassland treatment, and 11/30/2010 for animals from the natural grassland treatment. Slaughter followed the slaughterhouse routine and carcasses were evaluated according to the Brazilian carcasses grading system Ordinance 612/1989 (Brasil, 1989). Half-carcasses were stored in a cold room for 24 hours, and after this period $\mathrm{pH}$ $24 \mathrm{~h}$ post-mortem was measured. The right half of the carcass was weighed and cut into three primary cuts: forequarter, hindquarter and side cut. Those cuts were weighed to calculate their relationship to the entire carcass.

Carcass yield (CY kg/100 kg of live weight) was obtained using the equation $\mathrm{CY}=(\mathrm{HCW} / \mathrm{SW}) \times 100$, where $\mathrm{HCW}=$ hot carcass weight $(\mathrm{kg})$ and $\mathrm{SW}=$ slaughter weight measured on the farm (kg).

A portion of the longissimus muscle between the $12^{\text {th }}$ and $13^{\text {th }}$ rib with bones was taken off from each right half carcass. Those portions were packed in permeable plastic, then in paper, indentified and then frozen in a domestic freezer at $-18^{\circ} \mathrm{C}$ for $20,45,164$ days for natural Grassland, improved grassland and annual-summer grassland, respectively. The different freezing times were because of the distinct slaughter dates in the treatments. Measurements and analysis were carried out at Laboratório de Carnes of Embrapa CPPSUL in the city of Bagé/RS. Two 2.5-cm-thick samples (sample A and B) and a 1-cm-thick sample (sample $C$ ) were taken off from the frozen portion. Frozen samples "A" were weighed and then arranged on a tray covered with permeable plastic to be thawed in a refrigerator at $1.5-5^{\circ} \mathrm{C}$ for about 20 hours. Thawing losses were calculated by the difference between frozen and thawed weight. On thawed " $A$ " samples, after 30 minutes of oxygen exposure, color measurements of $\mathrm{L}^{*}$ (lightness) $\mathrm{a}^{*}$ (redness) and $b^{*}$ (yellowness) were taken according to CIE system, using a portable colorimeter Chroma Meter Cr-400 (Minolta Camera Co., Ltda., Osaka, Japan), iluminante D65, $10^{\circ}$ for standard observation, and calibrated for a white pattern. After removal of the remaining pieces of bones and fat from the sample, they were cooked in an oven at $180^{\circ} \mathrm{C}$ until the steak temperature reached $70^{\circ} \mathrm{C}$ in their geometric center. The temperature measurement was done using thermocouples in each beef. After cooking, steaks were chilled at room temperature and then weighed to calculate cooking losses.

Seven cores ( $1.27 \mathrm{~cm}$ diameter) were cut from the cooked and chilled "A" steaks parallel to the direction of the muscle fibers. Meat tenderness was evaluated by the maximum shear force in $\mathrm{kgf} / \mathrm{cm}^{2}$ in a Warner-Bratzler cell with a 1.016-mm blade coupled in Texture Analyzer TA-500 (Lloyd Instruments) using NEXYGEN software. Maximum shear force was logged for each sub-sample in NEXYGEN software curve. The average of seven sub-samples was used for each steak in the statistics analysis.

To evaluate water-holding capacity, $1 \mathrm{~cm}$-thick samples were submitted to the removal of superficial fat and then, the meat was triturated in a multiprocessor until it hand a homogeneous aspect. An aliquot of $2 \mathrm{~g}$ was taken from this paste, which was put between two sheets of filter paper and then submitted to a pressure of $10 \mathrm{~kg}$ weight for five minutes. Water-holding capacity values were expressed in $\mathrm{g} / \mathrm{kg}$ and were obtained by the equation (FW*1000/IW), 
where FW = sample weight after being submitted to pressure and IW = sample weight before being submitted to pressure (Grau \& Hamm, 1953, modified by Sierra, 1973). About $1.5 \mathrm{~g}$ of triturated sample was put in filter bags and sent to a dryer at $105^{\circ} \mathrm{C}$ for three hours in order to evaluate moisture. After that, aiming to quantify total lipids, fat extraction was carried out using an Ankon XT-20 Fat Analyzer for $60 \mathrm{~min}$ at $90^{\circ} \mathrm{C}$ in petroleum ether under nitrogen pressure. Total lipids content was expressed in $\mathrm{g} / \mathrm{kg}$ on the entire matter.

The " $B$ " samples were arranged on a tray, covered with permeable plastic and were thawed in a refrigerator at 1.5$5{ }^{\circ} \mathrm{C}$ for about 20 hours for sensory evaluation. After that, remaining pieces of bones and fat were removed from the samples, which were cooked in an oven at $180^{\circ} \mathrm{C}$ until the steak temperature reached $70^{\circ} \mathrm{C}$ in their geometric center. Steaks were cut in $1.5 \times 1.5 \mathrm{~cm}$ cubes, which were wrappedd in aluminum paper and kept warm at $60^{\circ} \mathrm{C}$. Sensory panel was composed of trained assessors who were familiarized with the technique and with the attributes that were going to be evaluated by ordination tests and semantic differential scales skills. A duo-trio test with eight assessors and three replicates were performed as discrimination method (ABNTNBR 13169, 1994). Assessors received three samples, one reference sample and two coded samples, one of them identical to reference samples. Assessors were asked to indicate which one of the two samples was equal to the reference sample, considering flavor and smell aspects. Results were obtained based on correct decisions, according to Roessler Table (Roessler et al., 1978).

The experimental design was completely randomized with a different number of replicates $(n=16,18,9$ for natural grassland, improved grassland and annual-summer grassland, respectively). Each animal was considered a replicate. Meat and carcass data were submitted to ANOVA and $\mathrm{F}$ test. When differences were detected, the Tukey test was done (PROC MIXED). To create a relationship between ultrasonic measurements and live weight, regression analysis was done (PROC REG). Models comparison was done by confidence interval of the biological parameters. Correlation analysis (PROC COR) and "stepwise" multiple regression (PROC STEPWISE) were done. Discrete variables were analyzed by chi-square test (PROC FREQ). Statistic analyses of the data were performed using the statistical software package SAS (Statistical Analysis System, version 9.2) adopting $\alpha=0.05$.

\section{Results and Discussion}

The decrease of the growth pace of the animals (Figure 1) fed in natural grassland in the fall is a classic behavior
(Grossmann \& Mordieck, 1956). This fact occurs due to the lower forage accumulation and quality of the pasture at this period of the year (Heringer \& Jacques, 2002). Similar behavior was obtained by Castilhos et al. (2007) in an improved system in the same physiographic region of the present study. The bodyweight loss observed in June and July on the improved grassland treatment may be due to the highest stocking rate used on the previous months in this treatment aiming to better establish the winter species. This managing must be reflected in lower sward structure, because even though presenting similar forage mass and canopy height, the animal performance was worse than obtained in natural grassland treatment. In July, probably due to a higher contribution of the exotic winter species on improved grassland, recovery of the bodyweight was observed, in a possible compensatory gain. Generally, aiming to provide better conditions to winter species establishment, studies that evaluated fattening cattle on improved-natural grassland had deferment conducted on these areas, with experimental animals removed to other areas during this period (Castilhos et al., 2007; Ferreira, 2009). However, as the present study was conducted to investigate possible relationships between kinds of grasslands and meat characteristics, experimental animals were kept in the same feeding systems during all experimental period.

The average daily gain between February and June $(0.824 \mathrm{~kg} /$ day $)$ obtained on the annual summer grassland allowed that the animals feeding on this system reached weigh and fat cover adequate to slaughter at ages lower than at other treatments.

Average daily gain values (Table 2) obtained with sorghum forage were lower than that reported by Restle et al. (2002), which was $1.121 \mathrm{~kg} \mathrm{LW} /$ day, but higher than those $0.631 \mathrm{~kg} \mathrm{LW} /$ day found by Neumann et al. (2005). Slaughter

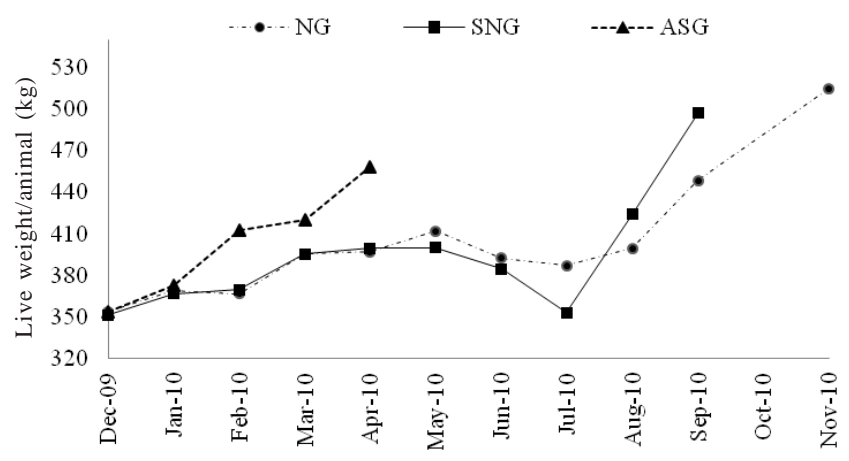

Figure 1 - Development of Aberdeen Angus steers (kg of live weight/animal) finished on natural grassland (NG), improved-natural grassland (ING) and annual summer grassland - sorghum (ASG).

R. Bras. Zootec., v.41, n.4, p.1051-1059, 2012 
weight was also lower in this treatment, which can be explained by the lower age. Cattle performances in natural grassland and improved-natural grassland were similar to those obtained by Castilhos et al. (2007) and Ferreira et al. (2011), who studied similar finishing systems.

Ultrasound analysis reflected the growth pace obtained with the treatments. Rib eye area development related to live weight (Figure 2) showed a linear behavior and nondependent on the treatment, which was different than the behavior described by Hamlin et al. (1995). However, in those studies, animals are conducted from $135 \mathrm{~kg}$ until $720 \mathrm{~kg}$, and the quadratic regressions obtained by them reflect the normal growth curve.

Fat deposition on biceps femoris at the P8 site (Figure 3) adjusted to a linear regression model for animals finished on the annual summer grassland and to a quadratic model for animals which were fed on natural grassland and improved natural grassland, following the animal weight gain curve. For relationships between fat thickness between the $12^{\text {th }}$ and $13^{\text {th }}$ ribs and live weight (Figure 4), the behavior was quadratic on the natural pasture and linear for improvednatural pasture and annual summer grassland. The linear behavior for animals that were fed the improved-natural pasture and annual summer pasture could be due to the higher forage mass and also forage quality at the most critical moment to finishing. In this case, animals which were fed with natural pasture, even having reached maturity and also having fat deposition on biceps femoris at the P8 site did not have enough quality in their diet to begin depositing fat between the $12^{\text {th }}$ and $13^{\text {th }}$ ribs, which is the least anatomic site for fat deposition (Di Marco, 1994). At slaughter, fat thickness between the $12^{\text {th }}$ and $13^{\text {th }}$ ribs and

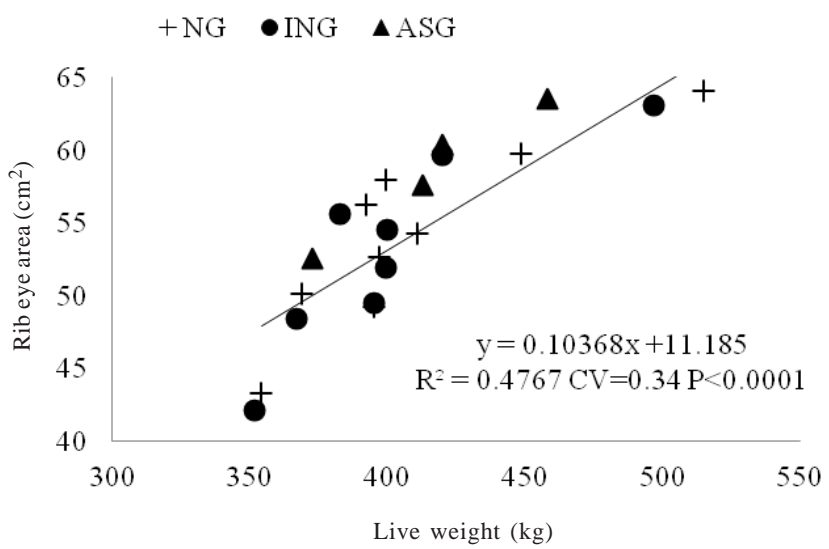

Figure 2 - Evolution of rib eye area between $12^{\text {th }}$ and $13^{\text {th }}$ rib as a function of live weight in Aberdeen Angus steers finished on natural grassland (NG), improved-natural grassland (ING) and annual summer grassland sorghum (ASG), measured by ultrasound.

Table 2 - Age at slaughter, weight at slaughter, average daily gain, carcass characteristics and meat physicochemical characteristics of Aberdeen Angus steers finished on natural grassland (NG), improved-natural grassland (ING) and annual-summer grassland (ASG)

\begin{tabular}{|c|c|c|c|c|c|}
\hline Variable & NG & ING & ASG & P-Value & $\mathrm{SE}$ \\
\hline Age at slaughter (days) & $1012 \mathrm{a}$ & $955 a$ & $860 b$ & 0.0009 & 17.32 \\
\hline Weight at slaughter (kg LW) & $514.8 \mathrm{a}$ & $496.9 a$ & $458.1 b$ & 0.0023 & 6.15 \\
\hline Average daily gain (kg LW/day) & $0.466 \mathrm{~b}$ & $0.491 b$ & $0.833 a$ & $<0.0001$ & 0.02 \\
\hline \multicolumn{6}{|l|}{ Carcass characteristics } \\
\hline Hot carcass weight (kg) & $251.4 \mathrm{a}$ & $258.0 \mathrm{a}$ & $225.6 b$ & 0.0008 & 3.30 \\
\hline Cold carcass weight (kg) & $246.6 a$ & $249.4 \mathrm{a}$ & $218.7 b$ & 0.0026 & 3.18 \\
\hline Carcass yield (kg/100 kg LW) & 48.9b & $51.9 \mathrm{a}$ & $49.2 b$ & $<0.0001$ & 0.30 \\
\hline Hindquarter yield (kg/100 kg cold carcass) & $46.4 \mathrm{~b}$ & $47.4 \mathrm{a}$ & $46.2 b$ & 0.0012 & 0.15 \\
\hline Forequarter yield (kg/100 kg cold carcass) & 37.8 & 37.1 & 38.0 & 0.1437 & 0.20 \\
\hline Sidecut yield (kg/100 kg cold carcass) & 15.8 & 15.5 & 15.8 & 0.5309 & 0.13 \\
\hline Fat thickness $-12^{\text {th }}$ and $13^{\text {th }}$ ribs $(\mathrm{mm})$ & 1.9 & 2.6 & 2.1 & 0.4014 & 0.22 \\
\hline Fat thickness - biceps femoris (mm) & 4.0 & 5.1 & 3.2 & 0.1158 & 0.34 \\
\hline Rib eye area $\left(\mathrm{cm}^{2}\right)$ & 63.0 & 63.1 & 63.6 & 0.9600 & 0.75 \\
\hline Ultimate $\mathrm{pH}$ & $5.67 \mathrm{~b}$ & $5.61 b$ & $5.85 a$ & $<0.0001$ & 0.02 \\
\hline \multicolumn{6}{|l|}{ Physicochemical characteristics of the meat } \\
\hline Thawing losses (g/kg) & $27.6 \mathrm{~b}$ & $36.0 \mathrm{a}$ & 23.9b & 0.0016 & 1.52 \\
\hline Cooking losses (g/kg) & $340.0 \mathrm{ab}$ & $351.9 a$ & $326.4 b$ & 0.0091 & 3.41 \\
\hline $\mathrm{L}^{*}$ & $35.3 \mathrm{ab}$ & $36.6 a$ & $34.6 b$ & 0.0117 & 0.27 \\
\hline$a *$ & 23.3a & $23.7 \mathrm{a}$ & $21.2 b$ & 0.0075 & 0.31 \\
\hline$b^{*}$ & $8.9 \mathrm{a}$ & $9.3 \mathrm{a}$ & $7.3 \mathrm{~b}$ & 0.0011 & 0.20 \\
\hline Water-holding capacity (g/kg) & $633.7 b$ & $672.5 \mathrm{a}$ & $681.8 \mathrm{a}$ & $<0.0004$ & 5.32 \\
\hline Moisture (g/kg) & 744.5 & 750.2 & 736.6 & 0.1054 & 2.81 \\
\hline Total lipids (g/kg) & 19.6 & 18.2 & 24.8 & 0.0640 & 1.11 \\
\hline Shear force $\left(\mathrm{kgf} / \mathrm{cm}^{2}\right)$ & $7.1 \mathrm{a}$ & 6.3ab & $5.5 b$ & 0.0563 & 0.25 \\
\hline
\end{tabular}

Means followed by distinct letters, in the same rows, are significantly different $(\mathrm{P}<0.05)$ by Tukey test.

SE - standard error; LW - live weight; $L^{*}$ - lightness, $a^{*}$ - redness e $b^{*}$ - yellowness. 
at the $\mathrm{P} 8$ site was similar $(\mathrm{P}>0.05)$ for animals in all treatments. This demonstrates that animals were slaughtered at similar physiological maturity (Table 2).

No effect of finishing systems was found on carcass conformation $(\mathrm{P}>0.05)$. Sub-rectilinear carcasses were most frequent (86\%), followed by rectilinear carcasses (14\%). Carcass conformation is a muscular expression evaluation that considers mainly the muscular covering of the hindquarter where the most valued cuts are located. However, this characteristic is more related with animal genetics than with feeding characteristics (Faturi et al., 2002; Vaz et al., 2005; Igarasi et al., 2008).

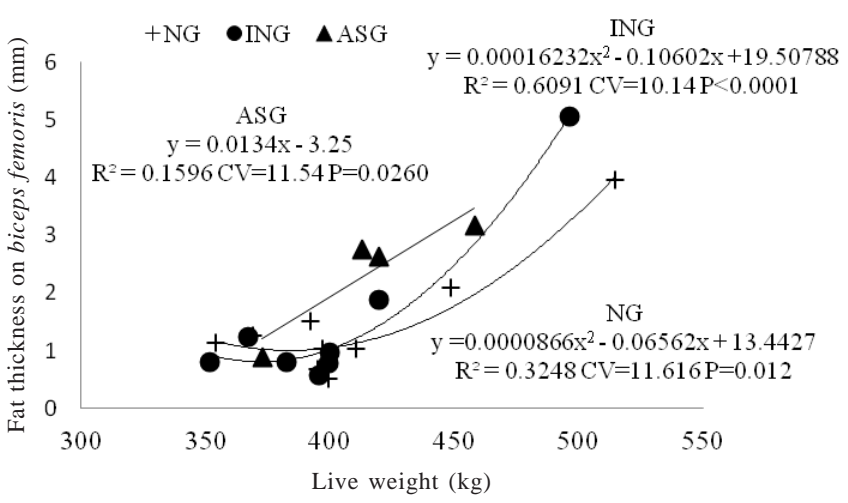

Figure 3 - Evolution of fat thickness on biceps femoris at the P8 site as a function of live weight in Aberdeen Angus steers finished on natural grassland (NG), improvednatural grassland (ING) and annual summer grassland sorghum (ASG), measured by ultrasound.

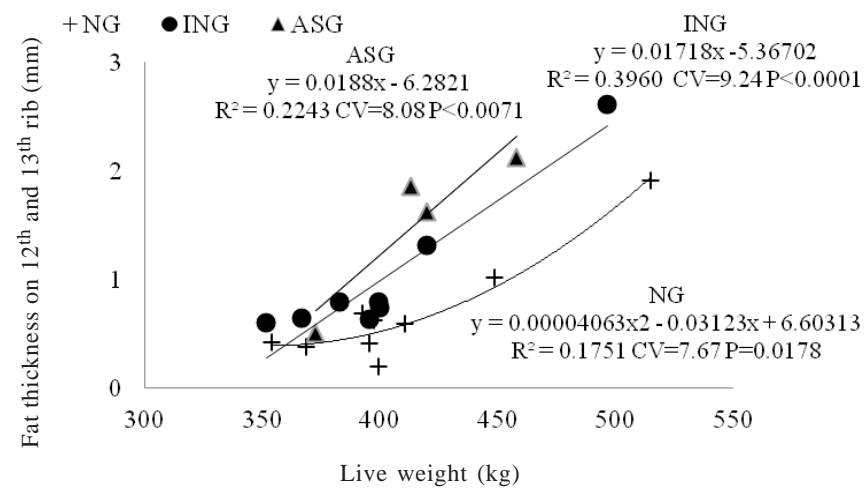

Figure 4 - Evolution of fat thickness on the $12^{\text {th }}$ and $13^{\text {th }}$ ribs as a function of live weight in Aberdeen Angus steers finished on natural grassland (NG), improved-natural grassland (ING) and annual summer grassland sorghum (ASG), measured by ultrasound.
Hot and cold carcass weight was lower in animals feeding on annual summer grassland $(\mathrm{P}<0.05)$ and similar between animals finished on natural grassland and improved-natural grassland ( $\mathrm{P}>0.05)$. These differences can be explained by the different ages at slaughter that occurred in the treatments. Carcass yield was higher $(\mathrm{P}<0.05)$ in improved-natural grassland. The higher contribution of Lolium multiflorum Lam. in this treatment could explain this result, since diets which have higher digestibility provide higher rate of passage, and then, lower ruminal fill, related with higher carcasses yields (Prado et al., 2000). However, this conclusion is not categoric; therefore, for the same animal type, other factors can influence this parameter, such as hours of fasting, and more or less rigidity at thecarcass toilet process.

Differences were not detected for forequarter yield or side-cut yield, and nor for rib eye area between finishing systems ( $\mathrm{P}>0.05$ ) (Table 2). According to Di Marco (1994), variations in the proportions of primary cuts in animals of same age and race are not frequent. These variations only take place when there are marked differences in the animal fat covering, which was not observed on the present study. Costa et al. (2002), working with Red Angus steers, verified that the slaughter weight evolution described linear decreasing behavior in the percentage of hindquarter and increasing behavior in forequarter percentage, with the side cut proportion remaining unaffected. In the present study, this behavior was not observed, since the hindquarter proportion was higher in animals finished in natural grassland; these animals presented the highest slaughter weights. In economic terms, it is desirable to obtain higher yields on hindquarter in relation to the other cuts, once is there that are situated the most valued cuts. These results are consistent with those obtained by Vaz et al. (2008) who found hindquarter yields of $47.7 / 100 \mathrm{~kg}$ in carcasses of 24-year-old Aberdeen Angus, fed rye-grass pasture.

Ultimate $\mathrm{pH}$ on meat corresponds to buildup of lactic acid coming from ATP resynsthesis from glycogen stores in muscle. Lower glycogen stores will cause higher ultimate $\mathrm{pH}$, which will compromise meat quality in many aspects (color, water-holding capacity, shelf-life, and others) (Lawrie, 2005). Acute stress before slaughtering is one of the causes of burning of glycogen. Higher $(\mathrm{P}<0.05)$ ultimate $\mathrm{pH}$ values were observed on carcasses from animals finished in Annual-summer grassland. Higher post-mortem $\mathrm{pH}$ values ( $\mathrm{pH}>5.8$ and $\mathrm{pH}<6.2$ ) occur more often in Bos indicus, which is probably due to their more reactive temperament, in contrast, Rossato et al. (2010) reported ultimate $\mathrm{pH}$ of 5,88 in Angus cattle. According to Neath et al., (2007) the meat from animals finished on grasslands has lower glycogen 
stores at slaughter, showing, hence higher ultimate $\mathrm{pH}$. In contrast, this statement was not verified in the present study, since the animals finished in natural grasslands and Improved-Natural grasslands showed adequate values (Table 2). Thereby, the higher values obtained in Annualsummer grassland cannot be awarded to the grassland, once these can be related to pre-slaughter management or even to industrial processing.

On meat physicochemical aspects (Table 2) there is no treatment effect for moisture or total lipids on edible portion $(\mathrm{P}>0.05)$. Intramuscular fat depends on fat thickness. Schoonmaker et al. (2003) suggest that to obtain meat with desirable sensorial attributes, it would be necessary to have $3.0 \%$ of intramuscular fat, which would correspond to 8-10 mm of fat covering.

Water-holding capacity is directly associated to fat content, and mainly to the speed of $\mathrm{pH}$ decrease during post-mortem glycolysis. In cases where there are no differences in meat lipid content, it is assumed that the variation would be determined by ultimate $\mathrm{pH}$ (Lawrie, 2005). This tendency was verified in the present study, since that meat of higher ultimate $\mathrm{pH}$ also presented higher water-holding capacity, $(r=0.3203 ; \mathrm{P}=0.0362)$.

Thawing and cooking losses are water-holding capacity linked. Higher thawing and cooking losses $(\mathrm{P}<0.05)$ were measured on meat from Improved-natural grassland and Annual-summer grassland. These variables were negatively correlated to ultimate $\mathrm{pH}$ values: $\mathrm{r}=-0.35(\mathrm{P}=0.0211)$ for thawing losses and $r=-0.43(P=0.0040)$ for cooking losses. This relation reflects the water attraction by the myofibril proteins that occur in higher $\mathrm{pH}$. In lower $\mathrm{pH}$, these proteins do not suffer any denaturation and so they keep their linkage site with water (Hedrick et al., 1994). Cooking losses were similar to the values reported by French et al. (2000) and Vaz \& Restle (2005).

In the present study, the age at slaughter did not affect meat color, once dark meats were found in both natural grasslands (oldest animals) and Annual-summer pastures (youngest animals). Multiple regression considering thawing losses, fat thickness, moisture, total lipids, $\mathrm{pH} 24$ hours post mortem, age at slaughter and freezing time as variables showed that thawing losses explained $28.43 \%$ of the $L^{*}$ value. This statement is consistent, once the lightness is influenced by the amount of water that is present in sample surface (Purchas, 1990). Thereby, darker meats could be verified in treatments where thawing losses were higher, which could be related to higher ultimate $\mathrm{pH}$ values. Redness $\left(a^{*}\right)$ is related to the amounts of red pigment in myoglobin and in cytochrome C (Hedrick et al 1983), which can be associated to physical activity and animal age.
Lower a* values were found in meats from Annual-summer pasture, which could be explained by lower slaughter ages, but this correlation was not significant $(\mathrm{r}=0.1095 ; \mathrm{P}=0.4842)$. On the other hand, the freezing time to which samples from these treatment were submitted (164 days) seems to be more related to $\mathrm{a}$ * than the slaughter age $(\mathrm{r}=-0.4465 ; \mathrm{P}=0.0027)$, in addition, the same could be set regarding $\mathrm{b}^{*}$ values $(\mathrm{r}=-0.5015 ; \mathrm{P}=0.0006)$. According the classification proposed by Abularach et al. (1998), the meats of the present study, regardless of treatment, all showed lightness from intermediate to dark, high red values and high yellow values; all of them are considered within the normal range for beef.

Higher shear force $(\mathrm{P}<0.05)$ was found in meats from natural grassland, whereas in Annual-summer grassland, lower shear forces were found. Shear force in meats from animals fed in Improved-natural pasture did not differ significantly from the other treatments. Some authors report that differences in grow rates could have impacts on particular kind of muscular fiber (Baillie \& Garlick, 1991), and consequently, on meat quality (Maltin et al., 2001). Reduced levels of food, and so, lower animal growth, can lead to a higher frequency of oxidative fibers and lower frequency of glycolitic fibers (Johnston et al., 1981, Seideman \& Crouse, 1986), which could be related to tougher meat (Zamora et al., 1996). Another approach to the effect of the grow rate is related to connective tissue composition. Gerrard et al. (1987) and Allingham et al. (1997) demonstrated that, in animal with high grow rates, the soluble collagen synthesis is higher. Compensatory gain also seems to influence the tenderness in beef (Andersen et al., 2005; Perry \& Thompson, 2005). According to the authors, the new collagen molecules which are synthesized during this period dilute the older molecules, which are insoluble, resulting in more tender meats. Thereby, it should be noted that besides the 24 hours in cold room, which is under the health laws, the analyzed samples did not take any ageing process.

Multiple regression considering thawing losses, fat thickness, moisture, total lipids, average daily gain, $\mathrm{pH} 24$ hours post mortem, age at slaughter and freezing time as variables showed that the average daily gain explained $18 \%$ of the shear force in meat $(\mathrm{P}=0.0092)$. Thereby, the intermediate values for shear force in meat from Improvednatural pasture suggests that the higher liveweight gains rate in the end of the fattening period in this system seems to have reflected in the tenderness improvement by collagen turnover as reviewed by Purslow (2005). Average values of shear force for animals finished in natural grassland were similar to those $7.86 \mathrm{kgf} / \mathrm{cm}^{2}$ reported by Rossato et al. 
(2010) in 36 months of age Angus cattle which were finished in pastures of Braquiária (Urochloa brizantha cv Marandu, Urochloa decumbens, Urochloa humidicula and Panicum maximum) and smaller than the $9.23 \mathrm{kgf} / \mathrm{cm}^{2}$ obtained by Vaz et al. (2007) in 24-month-old Angus cattle finished in a Lolium multiflorum grassland.

On the sensory evaluation by duo-trio test considering flavor and odor features, the assessors considered that beef samples from the evaluated feeding systems were different, obtaining 31correct judgments in 48 trials $(\mathrm{P}<0.05)$.

\section{Conclusions}

The finishing systems in natural grassland, Improvednatural grassland, and Annual Summer pasture enables desirable characteristics in the carcass and the meat of Aberdeen Angus cattle, until 34 months of age. The average daily gains defined by the feeding systems explained the differences in meat tenderness obtained in the different treatments. The evaluated finishing systems based on different pastures allowed the perception of distintic flavors and odors on meat of each treatment when analyzed by discrimination test in a trained sensory panel.

\section{Acknowledgements}

The authors thank CNPq, Estância do Silêncio de São José, Universidade Federal do Rio Grande do Sul, MARFRIG Group and EMBRAPA Pecuária Sul.

\section{References}

ABULARACH, M.L.S.; ROCHA, C.E.; FELÍCIO, P.E. Características de qualidade do contrafilé ( $\mathrm{m}$. L. dorsi) de touros jovens da raça Nelore. Ciência e Tecnologia de Alimentos, v.18, p.205-210, 1998.

ALLINGHAM, P.G.; HARPER, G.S.; HUNTER, R.A. Effect of growth path on the tenderness of the semi tendinosus muscle of Brahman-cross steers. Meat Science, v.48, p.65-73, 1997.

ANDERSEN, H.J., OKSBJERG, N., YOUNG, J.F. et al. Feeding and meat quality - a future approach. Meat Science, v.70, n.3, p.543-554, 2005.

ASSOCIAÇÃO BRASILEIRA DE NORMAS TÉCNICAS - ABNT. Teste Duo-Trio em análise sensorial-NBR13169. Rio de Janeiro: ABNT, 1994. 4p.

BAILLIE, A.G.; GARLICK, P.J. Responses of protein synthesis in different skeletal muscles to fasting and insulin in rats. American Journal of Physiology, v.260, p.E891-E896, 1991.

BENCKE, G.A. Diversidade e conservação da fauna dos campos do sul do Brasil In: PILLAR, V.P.; MÜLLER, S.C.; CASTILHOS, Z.M.S. et al. (Eds.) Campos Sulinos: conservação e uso sustentável da biodiversidade. Brasília: MMA, 2009, p.101-121.

BOLDRINI, I.I. Campos sulinos: caracterização e biodiversidade. In: ARAÚJO, E.L.; MOURA, A.N.; SAMPAIO, E.V.S.B. et al. (Eds.) Biodiversidade, conservação e uso sustentável da flora do Brasil. Recife: UFRP/Soc. Bot. Brasil, 2002. p.95-97.
BRASIL. Portaria ${ }^{\circ}$ 612, de 05 de outubro de 1989 aprova o sistema nacional de tipificação de carcaças bovinas. Diário Oficial da República Federativa do Brasil. Available at: <http:// extranet.agricultura.gov.br/sislegis/action/detalhaato.do? method=consultarlegislacaofederal $>$. Accessed on: Mar. 20, 2011.

CASTILHOS, Z.M.S.; NABINGER, C.; MACHADO, M.D. et al. Sistema de produção animal para recria e terminação de novilhos. Porto Alegre: Fepagro, 2007b. (Comunicado Técnico 15).

COSTA, E.C.; RESTLE, J.; VAZ, F.N. et al. Características da carcaça de novilhos Red Angus superprecoces abatidos com diferentes pesos. Revista Brasileira de Zootecnia, v.31, n.1, p.119-128, 2002.

DI MARCO, O.N. Crescimiento y respuesta animal. Buenos Aires: Associación Argentina de Producción Animal, 1994. 129p.

FATURI, C.; RESTLE, J.; BRONDANI, I.L. Características de carcaça e da carne de novilhos de diferentes grupos genéticos alimentados em confinamento com diferentes proporções de aveia e grão de sorgo no concentrado. Revista Brasileira de Zootecnia, v.31, n.5, p.2024-2035, 2002.

LÍCIO, P.E. Avaliação da qualidade da carne bovina. In: SIMPÓSIO SOBRE PRODUÇÃO INTENSIVA DE GADO DE CORTE, 1998, Campinas. Anais... São Paulo: Colégio Brasileiro de Nutrição Animal, 1998. p.92-99.

FERREIRA, E.T. Recria e terminação de novilhos de corte em pastagem natural submetida a diferentes manejos. 2009. 143f. Dissertação (Mestrado em Zootecnia) - Faculdade de Agronomia/Universidade Federal do Rio Grande do Sul, Porto Alegre.

FERREIRA, E.T.; NABINGER, C.; ELEJALDE, D.G. et al. Terminação de novilhos de corte Angus e mestiços em pastagem natural na região da Campanha do RS. Revista Brasileira de Zootecnia, v.40, p.2048-2057, 2011.

FRENCH, P.; O’RIORDAN, E.G.; MONAHAN F.J. et al. Meat quality of steers finished on autumn grass, grass silage or concentrate-based diets. Meat Science, v.56, p.173-180, 2000

GERRARD, D.E.; JONES, S.J.; ABERLE, E.D. et al. Collagen stability, testosterone secretion and meat tenderness in growing bulls and steers. Journal of Animal Science, v.65, n.5, p.1236-1242, 1987.

GONÇALVES E.N.; CARVALHO, P.C.F.; KUNRATH, T.R. et al. Relações planta-animal em ambiente pastoril heterogêneo: processo de ingestão de forragem. Revista Brasileira de Zootecnia, v.38, n.9, p.1655-1662, 2009.

GOTTSCHALL, C.S. Produção de novilhos precoces: nutrição, manejo e custos de produção. 2.ed. Guaíba: Agrolivros, 2005. 213p.

GRAU, R.; HAMM, R. Eine einfache methode zur bestimmung der wasserbindung in muskel. Naturwissenschaften, v.40, p.29-30, 1953.

GROSSMAN, J.; MORDIECK, K.H. Experimentação forrageira no Rio Grande do Sul. In: Rio Grande do Sul, Secretaria da Agricultura, Diretoria da Produção Animal (Ed.). Histórico da Diretoria da Produção Animal. Secretaria da Agricultura. Porto Alegre: Secretaria de Agricultura do RS, 1956. p.115-122.

HAMLIN, K.E.; GREEN, R.D.; PERKINS, T.L. et al. Real-Time Ultrasonic measurement of fat thickness and longissimus muscle area: I. Description of age and weight effects. Journal of Animal Science, v.73, p.1713-1724, 1995.

HEDRICK, H.B.; ABERLE, E.D.; FORREST, J.C. et al. Principles of meat science. 3.ed. Dubaque: Kendal/Hunt, 1994. 354p.

HEDRICK, H.B.; PATERSON, J.A.; MATCHES, A.G. et al. Carcass and palatability characteristics of beef produced on pasture, corn silage and corn grain. Journal of Animal Science, v.57, p.791-801, 1983.

HERINGER, I.; JACQUES, A.V.A. Qualidade da forragem de pastagem nativa sob distintas alternativas de manejo. Pesquisa Agropecuária Brasileira, v.37, n.3, p.399-406, 2002.

IGARASI, M.S.; ARRIGONI, M.B.; HADLICH, J.C. et al. Características de carcaça e parâmetros de qualidade de carne de 
bovinos jovens alimentados com grãos úmidos de milho ou sorgo. Revista Brasileira de Zootecnia, v.37, n.3, p.520-528, 2008. JOHNSTON, D.M.; MOODY, W.G.; BOLING, J.A. et al. Influence of breed type, sex, feeding system and muscle bundle size on bovine fiber type characteristics. Journal of Food Science, v.46, p.1760-1765, 1981.

LAWRIE, R.A. Ciência da carne. 6.ed. Porto Alegre: ARTMED, 2005. 384p.

MALTIN, C.A.; LOBLEY, G.E.; GRANT, C.M. et al. Factors influencing beef eating quality. 2. Effects of nutritional regimen and genotype on muscle fibre characteristics. Animal Science, v.72, p.279-287, 2001.

MOOJEN, E.L.; MARASCHIN, G.E. Potencial produtivo de uma pastagem nativa do Rio Grande do Sul submetida a níveis de oferta de forragem. Ciencia Rural, v.32, n.1, p.127-132. 2002.

MOTT, G.O.; LUCAS, H.L. The design, conduct and interpretation of grazing trials in cultivated and improved pastures. In: INTERNATIONAL GRASSLAND CONGRESS, 6., 1952, Pennsylvania. Proceedings... Pennsylvania: State College, 1952. p.1380-1385.

MUEHLMANN, L.D.; ROCHA, M.G.; RESTLE, J. Utilização de pastagem de estação quente com bovinos desmamados precocemente. Revista Brasileira de Zootecnia, v.26, n.3, p.584-589, 1997.

NABINGER, C.; SANT'ANNA, D.M. Campo nativo: sustentabilidade frente às alternativas de mercado. In: SIMPÓSIO DE FORRAGEIRAS E PRODUÇÃO ANIMAL, 2., 2007, Porto Alegre. Anais... Porto Alegre: Metrópole, 2007. p.83-121.

NEATH, K.E.; DEL BARRIO, A.N.; LAPITAN, R.M. et al. Difference in tenderness and $\mathrm{pH}$ decline between water buffalo meat and beef during post mortem aging. Meat Science, v.75, p.499-505, 2007.

NEUMANN, M.; RESTLE, J.; FILHO, D.C.A. et al. A qualidade de forragem e desempenho animal em pastagem de sorgo (Sorghum bicolor, 1.), fertilizada com dois tipos de adubo, sob pastejo contínuo. Revista Brasileira de Agrociência, v.11, n.2, p.221-226, 2005.

PERRY, D.; THOMPSON, J.M. The effect of growth rate during backgrounding and finishing on meat quality traits in beef cattle. Meat Science, v.69, p.691-702, 2005.

PRACHE, S.; THÉRIEZ, M. Traceability of lamb production systems: carotenoids in plasma and adipose tissue. Animal Science, v.69, p.29-36, 1999.

PRADO, I.N.; PINHEIRO, A.D.; ALCALDE, C.R. et al. Níveis de substituição do milho pela polpa cítrica peletizada sobre o desempenho e características de carcaça de bovinos mestiços confinados. Revista Brasileira de Zootecnia, v.29, n.7, p.2135- 2141, 2000.

PURCHAS, R.W. An assessment of the role of $\mathrm{pH}$ differences in determining the relative tenderness of meat from bulls and steers. Meat Science, v.27, p.120-140, 1990.

PURSLOW, P. Intramuscular connective tissue and its role in meat quality. Meat Science, v.70, p.435-447, 2005.
RESTLE, J.; FERREIRA, M.V.B.; SOARES, A.B. et al. Produção animal em pastagem nativa ou cultivada durante o período de verão. In: REUNIÃO ANUAL DA SOCIEDADE BRASILEIRA DE ZOOTECNIA, 33., 1996, Fortaleza. Anais... Viçosa, MG: Sociedade Brasileira de Zootecnia, 1996. p.438-440.

RESTLE, J.; ROSO C.; AITA, V. Produção animal em pastagem com gramíneas de estação quente. Revista Brasileira de Zootecnia, v.31, n.3, p.1491-1500, 2002 (supl.).

ROESSLER, E.B. et al. Expanded statistical tables for estimating significance in paired-preference, paired difference, duo-trio and triangle tests. Journal of Food Science, v.43, n.3, p.940-943, 1978.

ROSSATO, L.V.; BRESSAN, M.C.; RODRIGUES, E.C. et al. Parâmetros físicoquímicos e perfil de ácidos graxos da carne de bovinos Angus e Nelore terminados em pastagem. Revista Brasileira de Zootecnia, v.39, n.5, p.1127-1134, 2010.

SCHOONMAKER, J.P.; CECAVA, M.J.; FAULKNER, D.B. et al. Effect of source of energy and rate of growth on performance, carcass characteristics, ruminal fermentation and serum glucose and insulin of early-weaned steers. Journal of Animal Science, v.81, p.843-855, 2003.

SEBRAE/SENAR/FARSUL. Diagnóstico de sistemas de produção de bovinocultura de corte no estado do Rio Grande do Sul. Relatório. Porto Alegre: SENAR, 2005. 265p.

SEIDEMAN, S.C.; CROUSE, J.D. The efects of sex condition, genotype and diet on bovine muscle fiber characteristics. Meat Science, v.17, p.55-72, 1986.

SIERRA, I. Producción de cordero joven y pesado en la raza. Raza Aragonesa. I.E.P.G.E., n.18, 1973. 28p.

STRECK, E.V.; KÄMPF, N.; DALMOLIN, R.S.D. et al. Solos do Rio Grande do Sul. Porto Alegre: EMATER/RS; UFRGS, 2002. $107 \mathrm{p}$.

TOTHILL, J.C.; HARGREAVES, J.N.G.; JONES, R.M. Botanal a comprehensive sampling and computing procedure for estimating pasture yield and composition. I. Field sampling. Brisbane: CSIRO, Division of the Tropical Crops and Pastures, 1978. 20p. (Tropical Agronomy Technical Memorandum, 8).

VAZ, F.N.; RESTLE J.; METZ, P.A.M. et al. Características de Carcaça de novilhos Aberdeen Angus terminados em pastagem cultivada ou confinamento. Ciência Animal Brasileira, v.9, n.3, p.590-597, 2008.

VAZ, F.N.; RESTLE, J.; PADUA, J.T. et al. Qualidade da carcaça e da carne de novilhos abatidos com pesos similares, terminados em diferentes sistemas de alimentação. Ciência Animal Brasileira, v.8, n.1, p.31-40, 2007.

VAZ, F.N.; RESTLE, J. Características de carcaça e da carne de novilhos hereford terminados em confinamento com diferentes fontes de volumoso. Revista Brasileira de Zootecnia, v.34, n.1, p.230-238, 2005.

ZAMORA, F.; DEBITON, E.; LEPETIT, J. et al. Predicting variability of ageing and toughness in beef $\mathrm{M}$. Longissimus lumborum et thoracis. Meat Science, v.43, n.3-4, p.321-333, 1996. 